\title{
THE HISTORICAL FLOOD OF JULY 2008 FROM VASER RIVER BASIN, ROMANIA. CAUSES, EFFECTS AND FLOOD CONTROL ACTIONS
}

\author{
Andrei Sima ${ }^{1}$, Gheorghe Șerban ${ }^{1}$
}

Key words: flood, Vaser, causes, effects, reservoir.

\begin{abstract}
Floods is an experience perceived by society as unexpected, unexplainable and traumatizing and nowadays a threat to humanity more than ever. Among the natural phenomena which negatively affect human activities, floods are the ones which usually have the most significant consequences. The research, evaluations and statistics related to these phenomena do not reveal the drama and serious consequences that come with floods. It was proven that the increase of these extreme hydrological phenomena it is closely related to the anthropic activities from the area. Vaser basin is the most significant sub-basin of Vișeu river basin, contributing with $28 \%$ from the total flow of Vișeu river. Having a strong touristic and economic potential, the basin is often threatened by flash floods which usually have devastating effects. During July 2008 there was recorded the most significant flood from the history of hydrometric activity that led to substantial damage and death among locals. The present paper aims to analyze this historical flood, identifying the causes, effects, as well as the methods to control this extreme hydric phenomenon.
\end{abstract}

\section{Research premises}

Vaser river basin is located in the North extremity of Romania, at the transboundary ar ea with Ukraine, geographically occupying the central part of Maramureș Mountains, overlapping a large surface of Maramureș Mountains Natural Park. Administratively, Vaser river basin is located on the east side of Maramureș county, completely overlapping the administrative-territorial units of Vișeu de Sus town. (Fig. 1).

Part of Vișeu river basin, monitored by the Water Basin Administration Someș-Tisa, Vaser river basin borders Ruscova basin to the northwest and Țâșla

1 “Babeș - Bolyai" University, Cluj - Napoca; andrei.sima@geografie.ubbcluj.ro 
basin to the south. The river basin is drained by Vaser river, tributary of Vișeu, and its main tributaries are Puru, Făina, Novicior, Novăț, Scrada.

The most important aspects of the basin are related to the natural and anthropic conditions which favor flood occurrence, frequent and extreme phenomena that produce significant damage to Tipțerai and Vaser neighbourhoods of Vișeu de Sus, a town with a total number of 14239 inhabitants. There are several factors that influence flood occurrence in Vaser river basin, namely natural factors (climate, topography, geology, soil, vegetation) and anthropic factors (land clearings, land misuse); these factors are being identified and analyzed during the research.

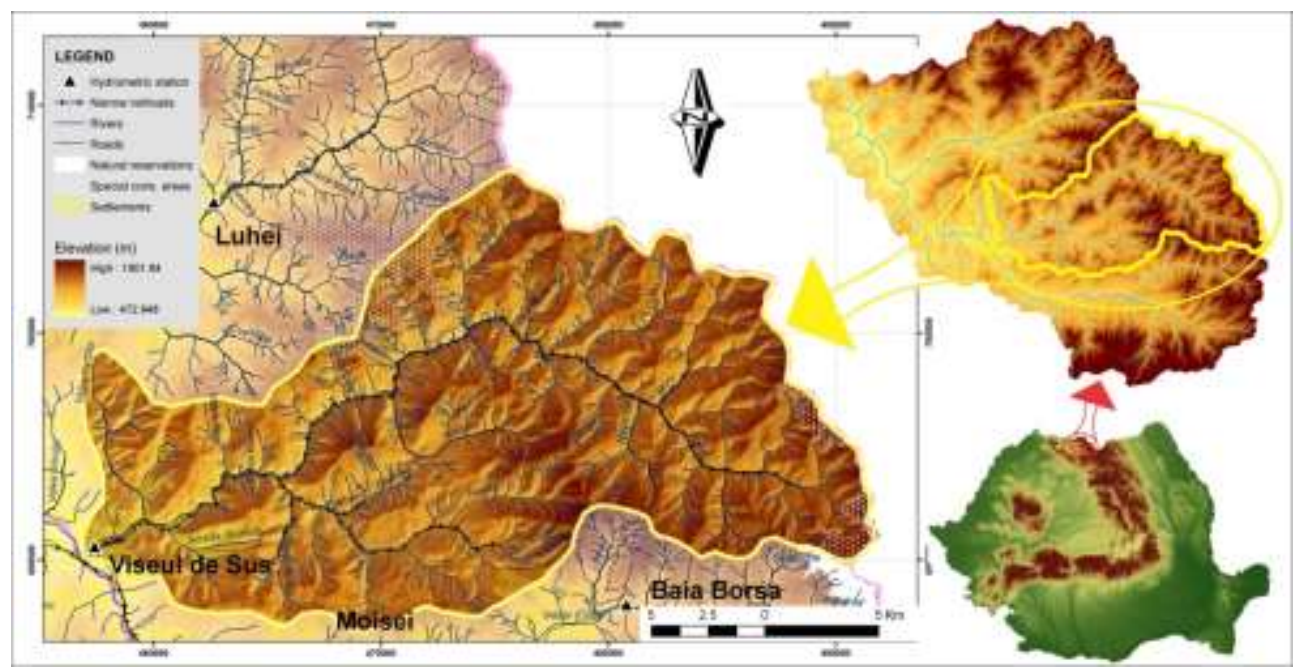

Fig. 1. Vaser basin localization.

By knowing the genesis and the specific mechanisms of these factors, their negative effects on an economic, social, ecological and geomorphological level can be reduced or eliminated. All of the involved factors have an important role in the development of these high risk hydric phenomena.

The most significant floods produced in Vaser river basin before 2008, occurred on May 12-15 1990, July 21-26 1974, December 23-29 1995, November 1998, March 2001, the latter one being the most significant until 2001.

\section{Methodology and database}

The present study is based on hydroclimatic data during the period between 1970-2008, cartographic and topographic support collected from the Water Basin Administration Someș-Tisa and local and county institutions, legislative framework as well as information collected onsite. Through detailed 
documentation, analysis, digital data processing with specialized softwares commonly used in hydrology and specialized studies (Microsoft Office Excel, ArcGIS, Cavis) there were drawn-up diverse thematic maps, cartographic components which led to the completion of the study. The water data used in the analysis of the flood of July 2008 has been collected from the Water Basin Administration Someş-Tisa, while the meteorological parameters have been collected from different specialized websites.

\section{Causes of the flood of July 2008}

The most important characteristic of a flood is the level of water in the riverbed. The flooding caused by the floods in Vaser river basin has affected the areas along the river where there is flooded grassland (the lower section of the basin), with the exception of the gorges and moors sectors along Vaser where floods do not occur even if the water levels are very high (the upper section of the basin). In order to analyze the flood which in 2008 has reached impressive values, a series of quantitative values of the recorded flood volumes and levels are needed.

The main causes of the flood were related to the climate. During the month in which the flood occurred, the layer of snow was definitely not present, but on the basis of the genesis of the flood was the heavy rainfall occurred in a very short period of time. In what follows a series of climatic parameters which generated the hydric phenomena are analyzed.

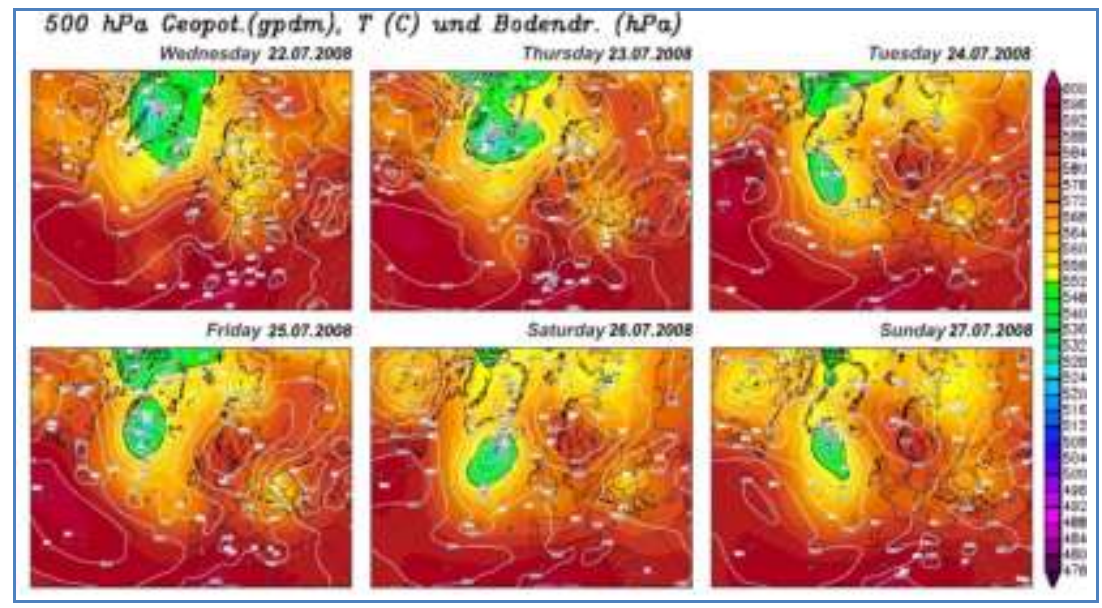

Fig. 2. Synoptic situation, July $22-27,2008$ (www.wetterzentrale.de).

Between the 20th and the 22nd of July 2008, a part of the extremely humid atmospheric front which affected Transylvania, Crișana and Maramureș has crossed the space between the Carpathians and the Balkans arriving over the Black 
Sea and reloaded with humidity. The movement of the front became in this way retrograde, transitioning from W-E to SW-NE, S-N, SE-NW, affecting the northern part of the Oriental Carpathians.

Between the 22nd and the 31st of July 2008 in Vaser river basin heavy precipitations have fallen. The rainfalls' volume have exceeded the monthly average (in 6 days it rained three times more than in a normal month of July), these being the ones which have generated the flood.

The synoptic situation of the 22nd -27th July describes a Scandinavian thalweg which formed a cold stationary nucleus generating torrential rainfalls over large areas of Romania, especially in the northern side of the country, in the Oriental Carpathians. (Fig. 2).

Heavy rainfall occurred during the same period in Vaser river basin which was estimated between $130-220 \mathrm{~mm}$ (Fig. 3), and even more, as we can say that over the flood generated at Vaser water springs, the waves from the tributaries were overlapped, especially from Novăt, leading to historical flows recorded by the Vișeu de Sus hydrometric station from Vaser river. (Table. 1).

Tab. 1. The caracateristics of the main Vaser basin flood waves (1970-2008).

\begin{tabular}{|c|c|c|c|c|c|c|c|c|c|c|}
\hline \multirow{2}{*}{ Year } & \multicolumn{2}{|c|}{ Flow $\left(\mathbf{m}^{\mathbf{3}} / \mathbf{s}\right)$} & \multicolumn{2}{|c|}{ Duration $(\mathbf{h})$} & \multicolumn{2}{|c|}{ Volume $\left(\mathrm{mil}^{\mathbf{3}} / \mathbf{s}\right)$} & hp (mm) & hs (mm) & $\boldsymbol{\alpha}$ \\
\cline { 2 - 12 } & max. & basic & total & rising & total & basic & rising & & & \\
\hline 1970 & 257 & 50.5 & 82 & 29 & 38.838 & 16.162 & 22.676 & 115 & 55.307 & 0.48 \\
\hline 1974 & 192 & 14.8 & 120 & 23 & 25.653 & 8.986 & 16.667 & 109.2 & 40.652 & 0.37 \\
\hline 1995 & 72.4 & 3.6 & 202 & 24 & 25.176 & 7.137 & 18.039 & 93 & 43.997 & 0.47 \\
\hline 1998 & 61.3 & 8.6 & 130 & 24 & 12.291 & 4.407 & 7.885 & 40 & 19.2 & 0.48 \\
\hline 2001 & 280 & 2.46 & 103 & 61 & 42.84 & 10.44 & 32.4 & 169 & 80 & 0.47 \\
\hline 2008 & 497 & 8 & 179 & 64 & 54.182 & 15.946 & 38.236 & 119.89 & 93.25 & 0.12 \\
\hline
\end{tabular}

$\mathrm{hp}(\mathrm{mm})=$ precipitate layer; hs $(\mathrm{mm})=$ drained layer; $\alpha=$ draining rate

Source: "Someș - Tisa" Basin Water Administration

The water evolution in these areas was characterized by producing in just 2-3 days an extremely violent flood with historical flows in Vaser river basin. (Fig. 4).

The total duration of the flood was of 179 hours, reaching a peak flow of 497 $\mathrm{m} 3 / \mathrm{s}$ on the 26th of July at 10:00 pm. The psychological impact of the flood was even greater when its peak level ( $\mathrm{H}, 0$ graphic” $-375 \mathrm{~cm})$ and flow was reached during the night.

Heavy rainfall occurred flooding the Vaser valley and after 24 hours another wave of rainfall affected the basin. The significant rainfall occurred between the 22nd and the 23rd of July 2008 totaling an estimated average of $48.4 \mathrm{~mm}$. 
The total estimated quantities which generated the flood, considered for the entire period between the $22 \mathrm{nd}$ and the 27 th of July 2008 , have had average values of $175 \mathrm{~mm}$.

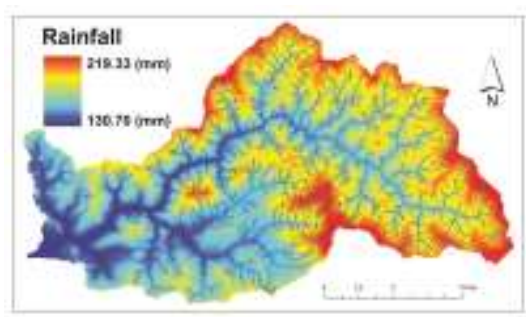

Fig. 3. The amount of rainfall during the period of July $22-27,2008$.

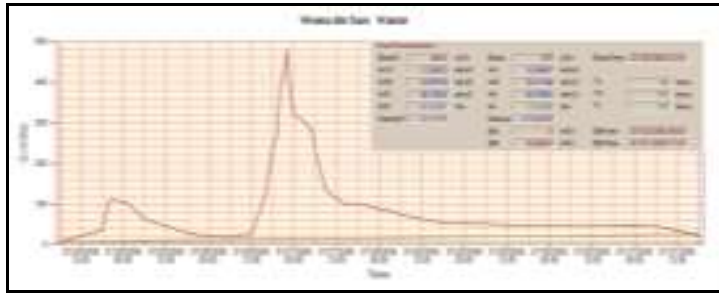

Fig. 4. Flood hydrograph, July $24-27,2008$.

The first increase in stream flow recorded by the hydrograph was generated by the rainfall between $22.07-23.07$, and the second one, more exactly the actual flood was produced by the rainfall between $24.07-27.07$. The lower sector of Vaser river was the most damaged one. The rainfall recorded after the 27th were not significant enough to influence the water level after the flood. The climate conditions during the period between July 24-27 were also influenced by other factors: the specific morphometry of the basin (assymetrical downstream confluence with Novăț), petrographic structure, the supersaturated soil and the frequent land clearings. All of the above mentioned factors have contributed to the genesis of the most significant flood in the history of hydric monitoring of Vaser river basin.

\section{Effects of the flood of July 2008}

The catastrophic floods of July 2008 have generated directly or indirectly significant damage, affecting both the social-economic sector and the environment (Fig. 4). Unfortunately, due to the hydro-climatic phenomenon 4 persons have lost their lives, one by drowning and the other 3 being killed by a landslide.

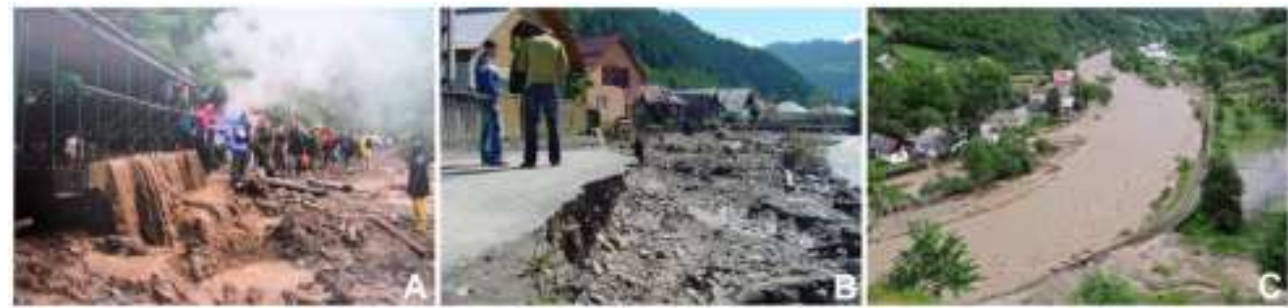

Fig. 4. The effects of the flood, 2008: A) „Mocănița” blocked on vaser Valley; B) Affected infrastructure; C) Flooded floodplain (source: A - Michael Schneeberger,2011; B, C www.emaramures.ro, 2008). 
According to the statements of the town hall of Vișeu de Sus after a first assessment the total value of the damage produced by the flood amounted to 9 mil. euros.

The balance of the damage resulted in the total destruction of four households, 9 homes were affected in a large proportion and another 68 in a smaller proportion. The restoration of these houses was financed by budgetary allocations through governmental decisions amounting to a total value of 58000 thousands of euro.

Damage to transport infrastructure and forestry railways was produced and electricity networks and power supply equipment were destroyed. Novicior, Novăt and Roșu bridges were damaged or destroyed, as well as footbridges and rural and forestry roads. Around 250 houses were isolated on Scradei Valley, towards Plaiului bridge, 200 houses on Rea Valley and about 100 on Peștilor Valley totaling a number of approximately 1700 inhabitants.

Due to the alluvium carried by the dark waters, the wells of the locals were clogged thing that required the help of the authorities in order to ensure drinking water in the affected area.

The forestry railway was impracticable, $30 \%$ of it being destroyed. The touristic train „Mocănița” which was operating on the 26th of July on Vaser Valley got stuck between the Făina and Bardău stations at km 24. 192 tourists got stuck on Vaser Valley and spent the night in ranger cabins. 130 of them were carried back by helicopter, while the others walked.

The entire riverbed area of Vaser has experienced river forming processes which directly affected the inhabited areas.

Halting the economy was one of the most important indirect effects, thing that affected the whole county's economy (timber exploitation in Vaser river basin bringing a huge contribution the county's economy), as well as the interruption of any other social, cultural and educational activity.

Unfortunately, due to the lack of complex hydro-technical facilities nothing could have been done in order to diminish the flows and to avoid damage caused by flood. There were only group actions to help the locals and to avoid other negative effects.

\section{Flood control actions}

There is a particular high interest to eliminate the calamities from Vaser Valley. In this case the most efficient methods are the structural ones, more exactly to develop a reservoir with a hydro-technical facility; even if this method may be expensive, it is way superior and effective than the existing ones. Once these risks are managed, the investment will bring a series of direct and indirect benefits locally and not only, during and after the developing activities: the improvement of the local infrastructure, creation of jobs; solution to the overall 
problem of floods on the downstream area, population safety, the possibility to develop a modern drinking water supply system, the recovery of the floodplain, the development of a new type of tourism due to the presence of the reservoir, new income from the production of electricity/tourism practice, the investment of funds in environmental protection and sustainable development of the area.

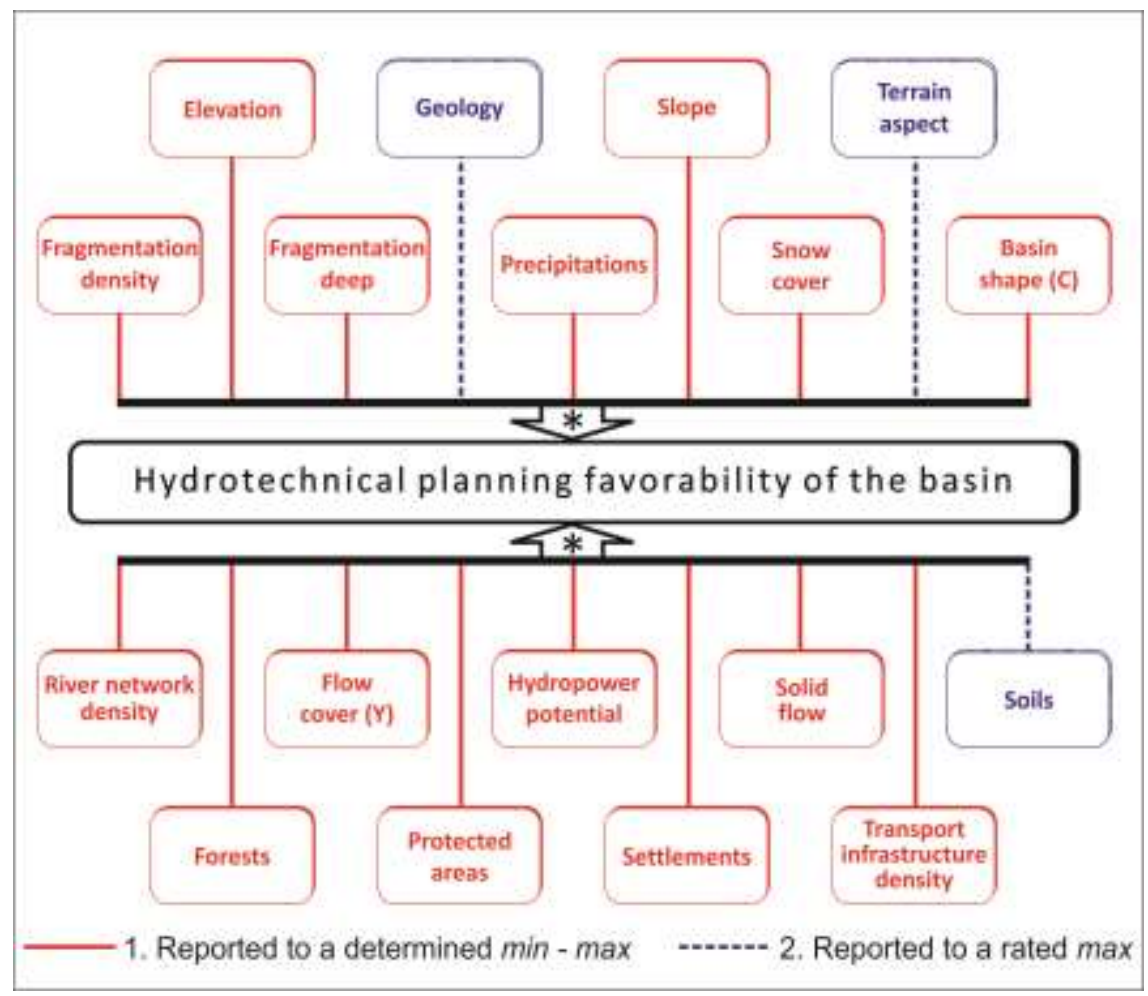

Fig. 5. Analyzed criteria for indexes determination.

Results. In order to analyze the development opportunities of Vaser river basin, 3 particular aspects were taken into consideration: the legislative framework (Art. 3 (5) Government Resolution 2151/2004), the natural environment and the anthropic environment. The detailed analysis of these 3 aspects also presented in other specialized papers (Șerban și colab, 2010, Sima, 2012) was followed by the proposal itself on the basis of identifying the development opportunities according to a favorability map and a favorability index identified on the basis of different criteria.

According to other papers (Gâștescu et al., 2003) the entire area of Vaser river basin comes under the first degree favorability area. As a consequence, in order to 


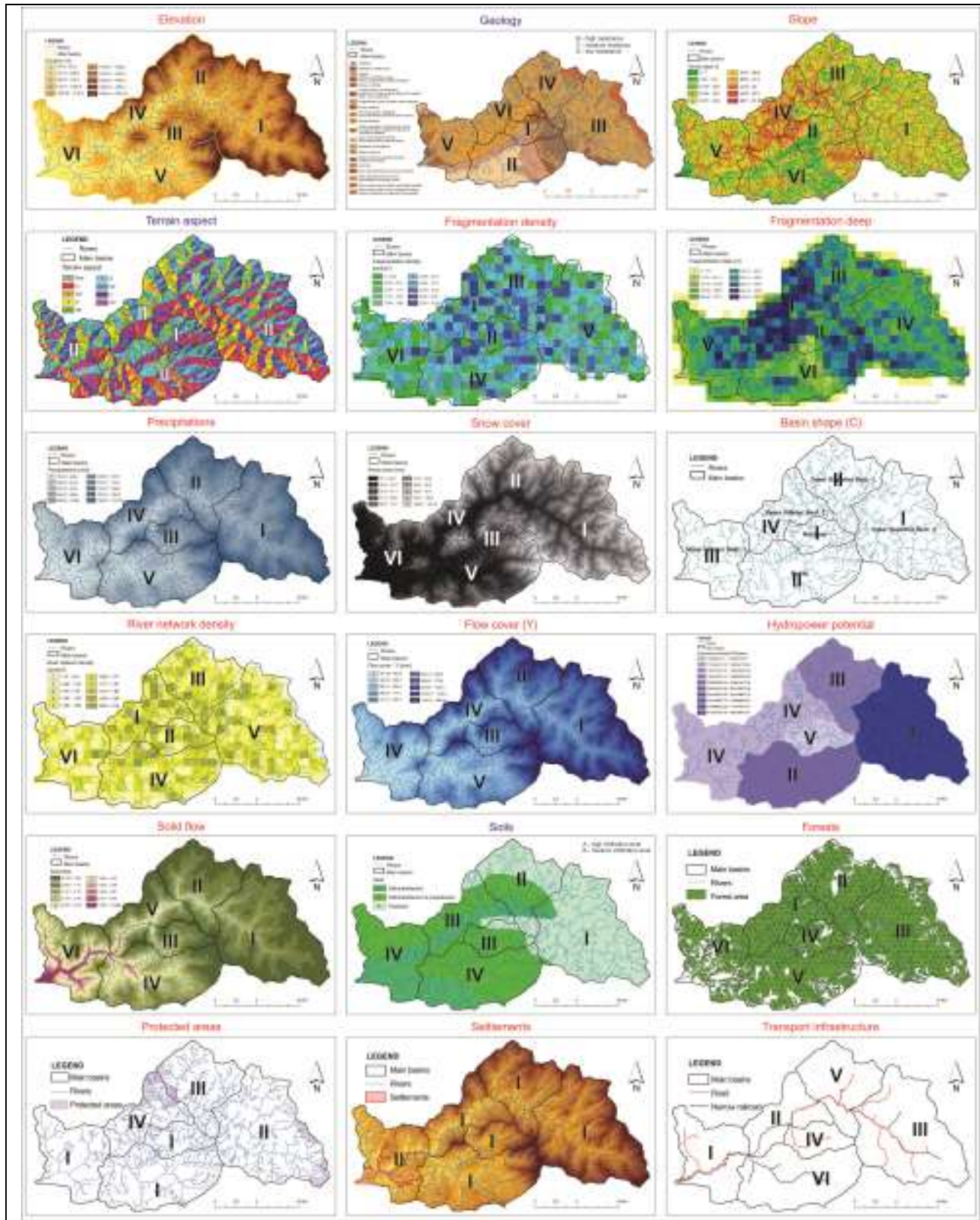

I - high favorability; II - increased favorability; III - it can be developed;

IV - it can be developed, but there are restrictions; V - less favorable; VI - unfavorable.

Fig. 6. Favorability maps according to analyzed criteria. 
identify the development opportunities of the basin, a detailed analysis of all natural and anthropic conditions from the basin was needed. First of all, the basin was divided into main sub-basins where the location of the reservoir was thought to be. With the help of the GIS specialized softwares, the sub-basins were analyzed qualitatively and quantitatively, taking into consideration 18 essential criteria for the development of Vaser river basin (Fig. 5).

Topographic, geological and pedological maps were georeferenced and digitized on the basis of GIS data. Using GIS methods and direct calculations there were determined certain basic parameters in order to analyze the above mentioned criteria creating different thematic maps. 6).

Tab. 2. Indexes, criteria and favorability.

\begin{tabular}{|c|c|c|c|c|c|c|}
\hline $\begin{array}{l}\text { LEGEND } \\
1 \text { - min } \quad 10 \text { - max } \\
\text { I- high favorability } \\
\text { II-increased favorability } \\
\text { III - it can be developed } \\
\text { IV-it can be developed, but there are restrictions } \\
V-\text { less favorable } \\
\text { VI- unfavorable }\end{array}$ & $\begin{array}{l}\text { ते } \\
\text { ह } \\
z\end{array}$ & $\frac{\dot{a}}{\stackrel{0}{0}}$ & 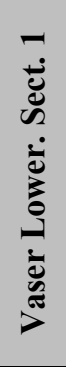 & 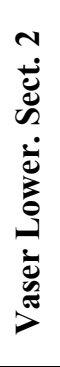 & 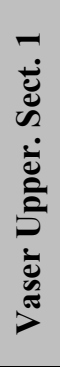 & 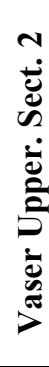 \\
\hline Elevation & 4 & 5 & 3 & 5 & 6 & 7 \\
\hline Geology & 4 & 10 & 2 & 1 & 3 & 4 \\
\hline Slope & 4 & 5 & 5 & 6 & 5 & 5 \\
\hline Terrain aspect & 3 & 5 & 3 & 3 & 3 & 3 \\
\hline Fragmentation density & 5 & 6 & 4 & 6 & 5 & 5 \\
\hline Fragmentation deep & 5 & 6 & 6 & 8 & 6 & 6 \\
\hline Precipitations & 4 & 5 & 3 & 5 & 6 & 7 \\
\hline Snow cover & 4 & 5 & 3 & 5 & 6 & 7 \\
\hline Basin shape $(C)$ & 4 & 5 & 2 & 1 & 4 & 5 \\
\hline River network density & 7 & 10 & 1 & 10 & 8 & 7 \\
\hline Flow cover $(\mathbf{Y})$ & 4 & 5 & 3 & 5 & 6 & 7 \\
\hline Hydropover potential & 5 & 1 & 2 & 2 & 4 & 10 \\
\hline Solid flow & 8 & 8 & 6 & 8 & 9 & 9 \\
\hline Soils & 1 & 2 & 1 & 2 & 7 & 10 \\
\hline Forests & 6 & 7 & 1 & 10 & 8 & 7 \\
\hline Protected areas & 10 & 10 & 10 & 1 & 7 & 7 \\
\hline Settlements & 10 & 10 & 1 & 10 & 10 & 10 \\
\hline Transport infrastructure density & 1 & 5 & 10 & 8 & 4 & 7 \\
\hline Favorability (Cat.) & IV & III & VI & $\mathbf{V}$ & II & $\mathbf{I}$ \\
\hline
\end{tabular}


The favorability index was determined in accordance with two principles: reference to a min-max previously determined through different procedures (correlations, regionalization, direct calculations) or reference to a max determined on the basis of certain parameters included in different classes.

In both cases the basic method used to calculate the average values implicitly the favorability index on each sub-basin was the weighted average in relation with the known parameters qualitatively determined or through different methods of calculation. The relevance and objectivity of the analysis is even greater as the number of the determined criteria is 15 compared to the 3 determined through calculation. In conclusion, as long as the method for the determination of a criterion is applied according to the same procedure for each sub-basin, the determination of the favorability index is correct. Each sub-basin was marked with favorability indices from 1 to 10 depending on the analyzed criteria (Table 2); after modelling all indices 6 favorability categories resulted (Fig. 7).

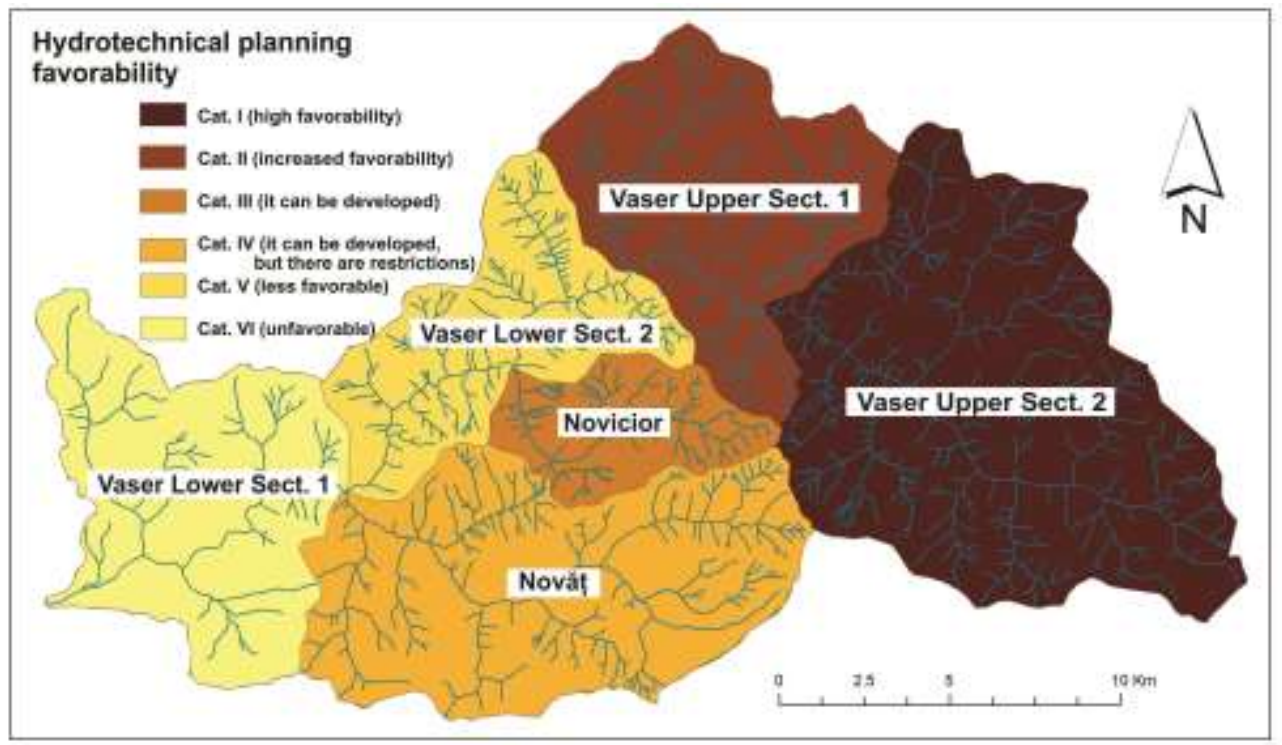

Fig. 7. Hydrotechnical planning favorability map of Vaser basin.

After the analysis of the basin and the identification of the most favorable subbasin for the development works, there has been made a GIS modelling of an arrangement located on the upstream of Vaser. The dimension of the reservoir was determined taking into consideration the dimensions of the recorded historical floods, the flood of July 2008 (Fig. 8). 
Discussions. In order to choose the criteria, the overlapping of the sub-basins with protected areas and localities from Maramureș Mountains Natural Park was particularly taken into account. The most favorable area for the development of the reservoir is sector 2 of the superior Vaser. Due to the advantage offered by the lack of settlements, non-overlapped valleys with protected areas, as well as a modern approach of construction methods with minimal impact on the environment, the idea of development of the hydro-technical facility is feasible.
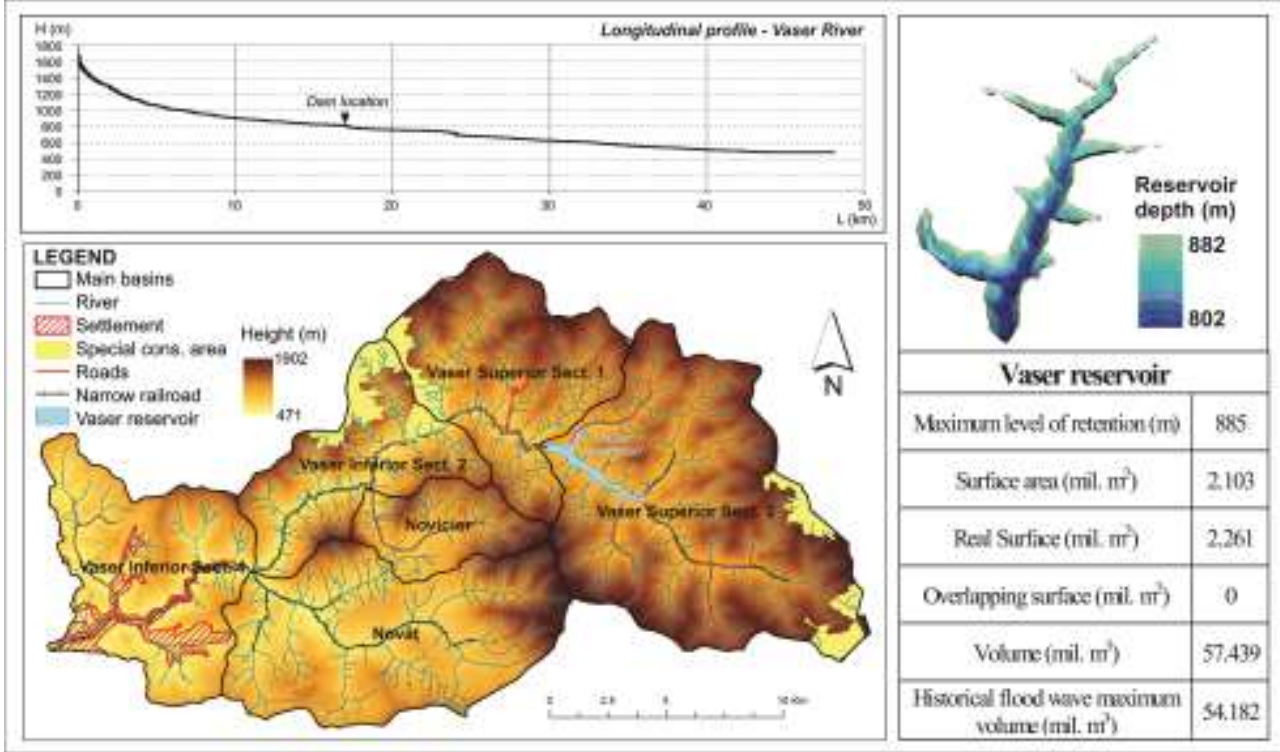

Fig. 8. Vaser reservoir localization and parametres.

The modelling based on as many relevant criteria as possible led to the creation of a very precise favorability map which can determine the localization and dimension of some potential reservoirs and hydro-technical facilities very necessary in Vaser river basin. According to the necessities and priorities of the analyzed basin, the main functions of the future reservoirs may be the following: flood mitigation, annual regulation of water flows on Vaser, water supply, power supply, tourist and recreational function.

In order to control floods in Vaser river basin it is necessary at least one reservoir with the previously mentioned dimensions. Analyzing the categories of favorability, for more efficiency the developement of cascade reservoirs may also be approached (case I - Superior Vaser Sect. 1 and Vaser Superior Sect. 2), on parallel streams (case II - Novicior and Novăț) or even mixed (case III - Superior Vaser Sect. 2 Novicior and Novăț). 


\section{Conclusions}

The present paper has emphasized a high necessity and development opportunity of Vaser basin, necessity influenced by the increased frequency of hydric risks and opportunity outlined by the great potential offered by the natural and anthropic enviroment of the area.

The advantage offered by the lack of settlements, non-overlapped valleys with protected areas, as well as a modern approach of construction methods with minimal impact on the environment, the idea of development of the hydrotechnical facility is feasible. The main condition is to provide a reservoir which can store at least the volume of water of the historical flood of 2008, or even greater if the reservoirs will be used as water supply systems for the nearby areas of Vaser.

\section{References}

Băloiu, V. (1980), Amenajarea a bazinelor hifrografice şi a cursurilor de apă, Edit. Ceres, Bucureşti.

Bilașco, Ș. (2008), Implementarea G.I.S. în modelarea viiturilor de versant, Casa Cărții de Ştiință, Cluj - Napoca.

Chiriac, V., Filotti, A., Manoliu, I.A. (1980), Prevenirea şi combaterea inundaţiilor, Edit. Ceres, Bucureşti.

Cocuţ, M. (2008), Teză de doctorat - Caracteristicile scurgerii apei din Depresiune Maramureşului în zona montană limitrofă, Univeristatea „Babeș - Bolyai”, Facultatea de Geografie, Cluj - Napoca.

Gâştescu P., Driga B., Sandu Maria (2003), Lacurile de baraj antropic - între necesitate şi modificări ale mediului, în vol. Riscuri şi catastrofe, vol. II, editor V. Sorocovschi, Casa Cărţii de Ştiinţă, Cluj Napoca.

Haidu, I. (1993), Evaluarea potenţialului hidroenergetic natural al râurilor mici Aplicaţie la Carpaţii Maramureşului şi Bucovinei , Edit. GLORIA în colaborare cu RENEL, Cluj - Napoca.

Hociug, C. (2010), Teză de doctorat - Studiul şi managementul fenomenelor naturale de risc şi hazard de pe teritoriul judeţului Suceava, Universitatea din Bucureşti, Facultatea de Geografie, București.

Mustățea, A. (2005), Viituri excepţionale pe teritoriul României - Geneză şi efecte, Bucureşti.

Schneeberger, M., (2011), Die Wassertalbahn, Berna.

Sima, A. (2012), Armonizarea mediilor natural și antropic în ariile protejate suprapuse bazinului Vișeu în paralel cu gestionarea riscurilor hidrice, Ed. Presa Universitară Clujeană, Cluj - Napoca.

Sima, A. (2015), The significant flash floods in Vișeu river basin, Romania. Causes and effects on the floodplain, Air and Wather components of the environment, Ed. Casa Cărții de Știință, Cluj - Napoca.

Sima, A., Lar, A. (2014), Proposal for hydropower development of the Ruscova basin, Romania, in order to mitigate floods as well as water and electricity supplies to the 
afferent area, Air and Wather components of the environment, Ed. Casa Cărții de Știință, Cluj - Napoca.

Şerban G., Pandi G., Sima A., Selagea H., (2010), Combaterea efectelor viiturilor din bazinul Vişeului prin amenajări hidrotehnice cu impact minimal asupra unor arii protejate, Institutul Naţional de Hidrologie şi Gospodărire a Apelor Conferinţa Ştiinţifică Jubiliară, 28-30 septembrie 2010.

Şerban G., Pandi G., Sima A., (2012), The need for reservoir improvement in Vișeu river basin in order to prevent flooding, with minimal impact on protected areas, Studia Univ. Babeș - Bolyai, Geographia, nr. 1/2012, Ed. Presa Universitară Clujeană.

*** (2005), Hotararea de Guvern nr. 2151 din 30 noiembrie 2004 privind instituirea regimului de arie naturală protejată pentru noi zone, publicată in Monitorul Oficial nr. 38 din 12 ianuarie 2005, Guvernul României, București.

*** (2009), Planul de management al spaţiului hidrografic Someş-Tisa, Administraţia Naţională „Apele Române” Direcţia Apelor Someş-Tisa. www.emaramures.ro 
